\title{
HUBUNGAN KEBISINGAN DENGAN STRES KERJA PADA PEKERJA
}

\author{
Mei Marisha*Cucu Herawati**
}

\begin{abstract}
ABSTRAK
Pekerjaan yang berada di ruang produksi benang dan tambang PT Arteria Daya Mulia (ARIDA) Cirebon memiliki intensitas kebisingan yang cukup tinggi. Salah satu dampak negatif yang ditimbulkan dari kebisingan, antara lain stres kerja seperti kurangnya konsentrasi dalam bekerja, sulit mengikuti pembicaraan, susah tidur dan berbicara dengan suara yang cukup keras. Tujuan dilakukannya penelitian ini adalah untuk mengetahui adanya hubungan antara kebisingan dengan stres kerja pada pekerja yang berada di ruang produksi benang dan tambang PT Arteria Daya Mulia (ARIDA) Cirebon. Penelitian ini menggunakan pendekatan deskriptif analitik dengan desain studi cross sectional. Instrumen yang digunakan adalah kuesioner. Pengumpulan data dengan teknik wawancara dan pengukuran terhadap kebisingan. Populasi dalam penelitian ini adalah pekerja yang berada di ruang produksi benang dan tambang PT Arteria Daya Mulia (ARIDA) Cirebon sebanyak 309 orang. Teknik pengambilan sampel menggunakan metode asidental sampel (accidental sampling) sebanyak 73 responden pada bulan Agustus 2015. Analisa data menggunakan univariat dan bivariat dengan uji chi-square. Berdasarkan hasil penelitan didapatkan sebanyak 52,1\% responden berada di ruang kerja kategori tidak bising dan kategori stres ringan 54,8\%. Hasil uji chi-square diperoleh nilai $p$ value $=0,015$, berarti terdapat hubungan antara kebisingan dengan stres kerja pada pekerja di bagian produksi benang PT Arteria Daya Mulia (ARIDA) Cirebon.
\end{abstract}

Kata kunci : Kebisingan, Stres Kerja, Pekerja

\begin{abstract}
Jobs that were in yarn and mine production room PT Arteria Daya Mulia (ARIDA) Cirebon has a high enough intensity noise. One of the negative impacts of noise, among others, job stress as a lack of concentration at work, it's hard to follow the conversation, insomnia and spoke in a voice loud enough. The purpose of this study was to determine the relationship between noise with job stress on employees in yarn and mine production room PT Arteria Daya Mulia (ARIDA) Cirebon. This study used a descriptive approach analytic cross sectional study design. The instrument used was a questionnaire. Collecting data with interview techniques and measurements of noise. The population in this study is the employees who are in yarn and mine production room PT Arteria Daya Mulia (ARIDA) Cirebon as many as 309 people. The sampling technique uses accidental sampling as many as 73 respondents in August 2015. Data were analyzed using univariate and bivariate with chi-square test. Based on the research results obtained as much as $52.1 \%$ of respondents were in the workplace are not noisy category and $54.8 \%$ mild stress category. The results of chi-square test obtained $\mathrm{p}$ value $=0.015$, it means that there is a relationship between noise with job stress on employees in yarn and mine production room PT Arteria Daya Mulia (ARIDA) Cirebon.
\end{abstract}

Keyword : Noise, Job Stress, Employee

\footnotetext{
* Alumni PSKM STIKes Cirebon Lulus Tahun 2015

** Staf Pengajar Program Studi S1 Kesehatan Masyarakat STIKes Cirebon
} 


\section{PENDAHULUAN}

Bising dalam kesehatan kerja, dapat diartikan sebagai suara yang menurunkan pendengaran baik kuantitatif (penurunan ambang pendengaran) maupun secara kualitatif (penyempitan spectrum pendengaran), berkaitan dengan faktor intensitas, frekuensi, durasi, dan pola waktu. Jadi dapat disimpulkan bahwa bunyi atau suara yang tidak dikehendaki dan dapat mengganggu kesehatan, kenyamanan serta dapat menimbulkan gangguan pendengaran seperti ketulian. Selain mengakibatkan gangguan kesehatan, kebisingan juga dapat mengakibatkan stres kerja. ${ }^{1}$

Stres kerja adalah suatu keadaan yang timbul dalam interaksi diantara manusia dengan pekerjaannya. Sehingga dapat disimpulkan stres kerja sebagai suatu kondisi dari hasil penghayatan subyektif individu yang dapat berupa interaksi antara individu dengan lingkungan kerja yang dapat mengancam dan memberi tekanan secara psikologis, fisiologis, dan sikap individu. ${ }^{2}$

Ada beberapa faktor intrinsik dalam pekerjaan dimana sangat potensial menjadi penyebab terjadinya stres dan dapat mengakibatkan keadaan yang buruk pada mental. Faktor tersebut meliputi keadaan fisik lingkungan kerja yang tidak nyaman seperti bising yang dihasilkan oleh mesin produksi, tempat kerja yang tidak ergonomis, kerja shift, jam kerja yang panjang, perjalanan ke dan dari tempat kerja yang semakin macet, pekerjaan beresiko tinggi dan berbahaya, pemakaian teknologi baru, pembenahan berlebih, adaptasi pada jenis pekerjaan baru dan lain-lain. ${ }^{3}$

PT Arteria Daya Mulia (ARIDA) bergerak dibidang industri tali temali (bijih plastik, benang nylon, tambang plastik dan jala ikan) termasuk industri tekstil. Teknologi yang digunakan PT Arteria Daya Mulia (ARIDA) adalah teknologi modern dan menggunakan mesin-mesin yang potensial untuk menghasilkan kapasitas produksi yang cukup tinggi.

Dalam proses produksi tersebut menggunakan mesin-mesin yang terdiri dari mesin samjin, mesin daekun, mesin winding, mesin twisting first, mesin twisting second, mesin extruder dan mesin gulungan yang mempunyai intensitas kebisingan tinggi yang dapat menyebabkan adanya gangguan pekerjaan ataupun penyakit akibat kerja berupa gangguan pendengaran. Hasil pengukuran kebisingan pada bulan April 2015 pada masing-masing mesin yaitu pada mesin samjin mencapai 118 dBA, mesin winder 95 dBA, mesin DaeKun 92 dBA, Twisting First $96 \mathrm{dBA}$, dan Twisting second sebesar $90 \mathrm{dBA}$, mesin extruder 83dBA, dan mesin gulungan sebesar $75 \mathrm{dBA}^{4}$

Tujuan penelitian ini untuk mengetahui hubungan kebisingan dengan stres kerja pada pekerja di ruang produksi benang dan ruang produksi tambang PT Arteria Daya Mulia (ARIDA) Cirebon tahun 2015.

\section{METODE PENELITIAN}

Jenis penelitian ini adalah penelitian dengan menggunakan metode analitik deskriptif dengan cara pendekatan cross sectional yaitu penelitian untuk mencari hubungan antar variabel. Pendekatan cross sectional adalah suatu penelitian untuk mempelajari dinamika kolerasi antara faktor risiko dengan cara pendekatan, observasi, atau pengumpulan data diukur atau dikumpulkan dalam waktu bersamaan atau sekaligus pada satu waktu. ${ }^{5}$ Populasi pada penelitian ini adalah semua pekerja di ruang produksi benang dan ruang produksi tambang PT Arteria Daya Mulia (ARIDA) yaitu sebanyak 197 pekerja di ruang produksi benang dan pekerja yang berada di ruang produksi tambang sebanyak 112 pekerja dengan total keseluruhan sebanyak 309. Teknik pengambilan sampel yang digunakan dalam penelitian ini adalah metode accidental yang merupakan cara pengambilan sampel dengan mengambil responden atau kasus yang kebetulan ada atau tersedia. ${ }^{6}$ Besar sampel dalam penelitian ini 
sebanyak 73 responden. Analisa data menggunakan univariat dan bivariat dengan uji chisquare.

\section{HASIL PENELITIAN Intensitas Kebisingan}

Tabel 1. Distribusi Frekuensi Berdasarkan Intensitas Kebisingan Pada Pekerja

\begin{tabular}{lll}
\hline Kebisingan & Frekuensi & Persentase $(\%)$ \\
\hline Bising $(\geq 85 \mathrm{dBA})$ & 35 & 47,9 \\
Tidak Bising $(<85 \mathrm{dBA})$ & 38 & 52,1 \\
\hline Jumlah & 73 & 100
\end{tabular}

Hasil penelitian pada tabel diatas menunjukan bahwa intensitas kebisingan pada pekerja diperoleh lebih dari sebagian responden berada pada kategori tidak bising yaitu 38 orang $(52,1 \%)$.

\section{Stres Kerja}

Tabel 2. Distribusi Frekuensi Berdasarkan Stres Pada Pekerja

\begin{tabular}{lll}
\hline Stres & Frekuensi & Persentase $(\%)$ \\
\hline Stres Ringan & 40 & 54,8 \\
Stres Sedang & 33 & 45,2 \\
Stres Tinggi & 0 & $0 \%$ \\
\hline Jumlah & 73 & 100 \\
\hline
\end{tabular}

Hasil penelitian pada tabel diatas menunjukan bahwa stres yang dialami oleh pekerja diperoleh lebih dari sebagian responden berada pada kategori stres ringan yaitu sebanyak 40 orang $(54,8 \%)$.

\section{Hubungan Kebisingan dengan Stres Kerja}

Tabel 3. Hubungan Kebisingan dengan Stres Kerja Pada Pekerja

\begin{tabular}{|c|c|c|c|c|c|c|c|c|c|}
\hline \multirow{3}{*}{ Kebisingan } & \multicolumn{6}{|c|}{ Stres Kerja } & \multirow{2}{*}{\multicolumn{2}{|c|}{ Jumlah }} & \multirow{2}{*}{ P Value } \\
\hline & \multicolumn{2}{|c|}{ Stres Ringan } & \multicolumn{2}{|c|}{ Stres Sedang } & \multicolumn{2}{|c|}{ Stres Tinggi } & & & \\
\hline & $\mathrm{N}$ & $\%$ & $\mathrm{~N}$ & $\%$ & $\mathrm{~N}$ & $\%$ & $\mathrm{~N}$ & $\%$ & \\
\hline Tidak Bising & 26 & 68,4 & 2 & 31,6 & 0 & 0 & 38 & 100 & \\
\hline Bising & 14 & 40 & 1 & 60 & 0 & 0 & 35 & 100 & 0.015 \\
\hline Jumlah & 40 & 54,8 & 33 & 45 & 0 & 0 & 73 & 100 & \\
\hline
\end{tabular}

Berdasarkan tabel 3 telah didapatkan responden yang berada di dalam area ruang kerja tidak bising didapatkan sebagian besar mengalami stres ringan sebesar $26(68,4 \%)$ dan responden yang bekerja di ruang bising sebagian besar mengalami stres sedang yaitu sebesar $21(60 \%)$ responden. Hasil uji bivariat dengan dengan menggunakan uji chi-square menunjukan nilai $p$ value $=0,015(\alpha=0,05)$. Hal ini menunjukan adanya hubungan antara 
kebisingan dengan stres kerja di ruang produksi benang dan ruang produksi Tambang PT Arteria Daya Mulia (ARIDA) Kota Cirebon Tahun 2015 ( $\mathrm{p}=0,015 ; \alpha=0,05$ ).

\section{PEMBAHASAN}

Berdasarkan hasil analisa data hubungan kebisingan dengan stres kerja pada pekerja di ruang produksi benang dan tambang PT Arteria Daya Mulia (ARIDA) Cirebon dengan menggunakan uji chi-square menunjukan nilai $p$ value $=0,015(\alpha=0,05)$. Hal ini menunjukan terdapat hubungan antara kebisingan dengan stres kerja di ruang produksi benang dan tambang PT Arteria Daya Mulia (ARIDA) Cirebon.

Hasil penelitian ini sesuai dengan penelitian yang dilakukan oleh Aripta Pradana (2013) yang menyatakan bahwa ada hubungan antara kebisingan dengan stres kerja. Hasil tersebut didukung oleh penelitian Suksmono (2013) yang menyatakan bahwa ada hubungan antara intensitas kebisingan dengan stres kerja. ${ }^{7}$

Menurut PERMENAKERTRANS No. PER.13/X/2011 Tahun 2011 semua suara yang tidak dikehendaki yang bersumber dari alat-alat proses produksi dan atau alat-alat kerja yang pada tingkat tertentu dapat menimbulkan stres kerja. Kebisingan merupakan salah satu faktor fisik lingkungan kerja yang dapat menimbulkan dampak pada gangguan pendengaran (audiotory) dan extra audiotory seperti stress kerja/psikologik, hipertensi, kelelahan kerja dan perasaan tidak senang (annoyance) ${ }^{8}$ Hal tersebut didukung oleh penelitian yang dilakukan Aripta Pradana Tahun 2013 menyatakan bahwa stres kerja karena kebisingan, seperti susah tidur, sulit konsentrasi dan sebagainya. Kemungkinan stres kerja tersebut, diakibatkan karena tingkat kebisingan yang melewati nilai ambang batas (NAB). ${ }^{9}$

Sumber bising dapat diidentifikasikan jenis dan bentuknya. Kebisingan yang berasal dari berbagai peralatan memiliki tingkat kebisingan yang berbeda-beda dari model ke model lain. Proses pemotongan seperti proses penggergajian kayu merupakan sebagian contoh bentuk benturan antara alat kerja dan benda kerja yang menimbulkan kebisingan. Penggunaan gergaji bundar dapat menimbulkan tingkat kebisingan antara $80-120 \mathrm{~dB} .{ }^{10}$

Berdasarkan uraian hasil dan teori di atas dapat disimpulkan bahwa menurut peneliti stres kerja disebabkan oleh kebisingan, dimana gangguan pendengaran di tempat kerja dipengaruhi oleh kebisingan yang disebabkan dari alat-alat proses produksi dan atau alat-alat kerja yang pada tingkat tertentu dapat menimbulkan stres kerja.

\section{SIMPULAN}

1. Intensitas kebisingan pada pekerja diperoleh lebih dari sebagian responden berada pada kategori bising sebanyak 35 orang (47,9\%) dan kategori tidak bising yaitu sebanyak 38 orang $(52,1 \%)$. Hal ini disebabkan oleh tingkat kebisingan di PT Arteria Daya Mulia (ARIDA) yang rata-rata masih berada di bawah NAB.

2. Sebanyak 35 responden dengan kategori bising $60 \%$ mengalami stres sedang dan $40 \%$ mengalami stres ringan, sedangkan dari 30 responden dengan kategori tidak bising $68,4 \%$ mengalami stres ringan dan 31,6\% mengalami stres sedang. Hal ini disebabkan oleh intensitas kebisingan yang mempengaruhi stres kerja.

3. Terdapat hubungan antara kebisingan dengan stres kerja di ruang produksi benang dan tambang PT Arteria Daya Mulia (ARIDA) Cirebon $(\mathrm{p}=0,015 ; \alpha=0,05)$.

\section{SARAN}

1. Untuk PT Arteria Daya Mulia (ARIDA) Cirebon

1) Memberikan atau menyediakan fasilitas kesehatan seperti $P 3 K$ yang lebih lengkap dan juga memberikan pemeriksaan rutin atau pemeriksaan berkala bagi karyawan. 
2) Meningkatkan waktu pengawasan dan pemantauan terhadap pelaksanaan pengendalian kebisingan dan resiko penurunan daya dengar serta stres kerja yang dialami oleh karyawan.

3) Pemberian reward atau penghargaan pada karyawan teladan yang telah bekerja sesuai dengan standar operasional prosedur perusahaan.

2. Untuk kepala ruang produksi benang dan ruang produksi tambang PT Arteria Daya Mulia (ARIDA) Cirebon

1) Melakukan monitoring lingkungan kerja (kebisingan) secara rutin.

2) Melakukan pengendalian bahaya pada mesin atau sumber bising dengan cara perawatan mesin, isolasi, memberikan peredam bunyi.

3) Memberikan pelatihan kepada pekerja dalam mengatasi kebisingan dan stres kerja dilingkungan kerja.

4) Melakukan pengendalian secara subtitusif seperti mengganti peralatan yang sudah menimbulkan bising yang terlalu tinggi.

5) Melakukan pengendalian secara eliminatif yaitu dengan cara menghilangkan sumber bising yang ada.

6) Melakukan pengendalian secara engineering seperti membuat shelter untuk pegawai supaya tidak terpapar bising terlalu tinggi.

7) Dilakukan pembinaan mengenai pentingnya penerapan dan penggunaan alat pelindung diri (APD) pada saat sedang bekerja.

8) Memberikan sanksi kepada pekerja yang tidak menggunakan Ear Muff atau Ear Plug.

3. Untuk karyawan atau pekerja PT Arteria Daya Mulia (ARIDA) Cirebon

1) Gunakan alat pelindung diri (Ear Muff atau Ear Plug) dengan baik dan benar pada saat sedang bekerja.

2) Patuhi peraturan dalam bekerja.

3) Bekerja sesuai dengan standar operasional prosedur yang telah diterapkan oleh perusahaan.

\section{DAFTAR PUSTAKA}

1. Wardana. Laporan praktikun kebisingan/sound level meter; [diakses tanggal 17 April 2015]. Diunduh dari: http://wardana-sl.blogspot.com/2012/07/laporanpraktikumkebisingan-sound.html

2. Sutarto Wijono. Psikologi Industri dan Organisasi. Jakarta: Kencana Prenanda Media Group; 2010

3. Tarwaka, Solichul HA, Bakri, Lilik Sudiajeng. Ergonomi Industri Dasar dasar Pengetahuan Ergonomi dan Aplikasi di Tempat Kerja. Surakarta: Harapan Press; 2010

4. Dokumen Perusahaan PT Arteria Daya Mulia (ARIDA) Cirebon

5. Soekidjo Notoatmodjo. Metodologi Penelitian Kesehatan. Jakarta: PT. Rineka Cipta; 2005

6. Sugiono. Statistik Untuk Penelitian. Dalam: Sugiono. Statistik Penelitian. Bandung; 2007

7. Suksmono. Hubungan Antara Intensitas Kebisingan dan Iklim Kerja Dengan Stres Kerja Pada Pekerja Di Bagian Produksi PT Nusantara Building Industries (NBI). Lib.unes.ac.id; 2013

8. Tana. Pengertian Bising dan Bahaya Kebisingan di Tempat Kerja; [diakses tanggal 1 Juni 2015]. Diunduh dari : http://cerminduniakedokteran.com/2002/intisari/bising.htm

9. Pradana. Hubungan Antara Kebisingan dengan Stres Kerja Pada Pekerja Di Bagian Gravity PT. Dua Kelinci; 2013

10. Sihar Tigor.B.T, Kebisingan Di Tempat Kerja. Yogyakarta: ANDI; 2005 